\title{
Study on the benefit of solar optoelectronic policy in Kaohsiung
}

\author{
Tsai Chang-Chang ${ }^{\mathrm{a}}$, Kao Kuo-Sheng ${ }^{\mathrm{b} *}$, Huang Chi-Ming ${ }^{\mathrm{a}}$, Li Yen-Yic ${ }^{\mathrm{c}}$, Chiang Chun-Chang, \\ Liu Chung-Ang, ${ }^{\mathrm{a}}$ Yu Chun-Ming ${ }^{\mathrm{a}}$, Chung Po-Ren ${ }^{\mathrm{d}}$, Lin Chia-Shiung ${ }^{\mathrm{c}}$ \\ ${ }^{a}$ Bureau of Public Works, Kaohsiung City Government, Taiwan, \\ ${ }^{\mathrm{b}}$ Department of Computer and Communication, SHU-TE University, Taiwan \\ ${ }^{c}$ Department of Interior Design, SHU-TE University, Taiwan \\ ${ }^{\mathrm{d}}$ Graduate School of Architecture, National Cheng-Kung University, Taiwan \\ ${ }^{*}$ Corresponding author.+886-7-6158000 ext. 4818, E-mail address: kks@stu.edu.tw
}

\begin{abstract}
Over the years, Kaohsiung City has gone through extensive measures to become its own city. In total, Installment capacity increase of $300,000 \mathrm{~kW}$ (or $300 \mathrm{MW}$ ), generated 380 million $\mathrm{kWh}$ of power annually, It can provide the monthly electricity consumption of 104,510 households. Carbon sequestration of about 113 Kaohsiung metropolitan Parks, and created a PV industry with a net worth of NTD 28 billion. This study looks at the evidence of achievements the city has made promoting scientifically meaningful architectural aesthetics in its innovative green buildings and energy technology, as well as the success it has seen pushing the policies through a bottom-up structure. In conclusion, it can be said that, using a model based on a project developed by our institute, the Kaohsiung City Government has successfully made the renewable energy become an integral part of Kaohsiung's lifestyle, creating a threefold win for the government, the institute, and the people of Kaohsiung.
\end{abstract}

Key words: Solar photovoltaic, Policy, The city of green daylight, Low carbon

\section{Introduction}

Working in coordination with Kaohsiung's climate, the Kaohsiung City Government set the goal to generate $150 \mathrm{MW}$ worth of solar photovoltaic power within four years. It set up an interdepartmental task force to collectively promote the photovoltaic systems within the following five categories: general constructions, public buildings, schools, factories, and fishing and agricultural facilities.

The Kaohsiung City Government set the four-year goal as a means to fulfill its global responsibilities against greenhouse effect as well as to take care of its citizens in the long run by implementing its core values of bringing "ecology, economy, livability, creativity, safety, and internationality" into their daily lives.

\section{Policies and Strategies}

With global warming on the rise, the Kaohsiung City Government was ahead of its time when it initiated its photovoltaic project prior to the promulgation of Taiwan's Renewable Energy Development Act. While the city's geological climate rendered it a suitable candidate for solar energy, the reality on the ground was that current building regulations, the conditions of existing structures, and the price of setting up photovoltaic panels had made it hard to promote solar power on a city-wide scale. Having identified these obstacles, the government saw a need to relax existing laws while aggressively pushing, promoting, and subsidizing photovoltaic constructions. It also listed the photovoltaic project among its priority policies for better effect. Therefore, the Kaohsiung municipal government proposed the four year plan and the specific ten action plan, (Table I)

The Kaohsiung City Government took action with a series of policies to increase solar energy production. Firstly, it established an operating network by forming an inter-departmental task force to promote photovoltaic (PV) systems in the public and private sectors. It also linked professional organizations with local communities, and set up a dedicated hotline for consultation and inquiries. Secondly, it strengthened its photovoltaic infrastructure through formal statutes and regulations. This includes the announcement of a series of official solar photovoltaic policies, the promulgation of a floor area ratio incentive, and the enforcement of mandatory policies to increase photovoltaic implementation. Thirdly, it designated target sites to serve as examples of the project. This includes installing photovoltaic systems on public rooftops, building photovoltaic demonstration zones, transforming illegal structures into solar power providers, and assisting the fishing and agricultural sectors in building photovoltaic systems.

TABLE I

KAOHSIUNG GOVERNMENT PUT FORWARD THE SPECIFIC TEN ACTION PLAN

\begin{tabular}{|c|c|}
\hline \multirow{3}{*}{$\begin{array}{c}\text { Creating an } \\
\text { Operating } \\
\text { Network }\end{array}$} & 1. Appointing an interdepartmental task force. \\
\hline & $\begin{array}{l}\text { 2. Giving local communities professional } \\
\text { assistance }\end{array}$ \\
\hline & 3. Setting up a dedicated hotline \\
\hline \multirow{3}{*}{$\begin{array}{c}\text { Utilizing } \\
\text { Policy as } \\
\text { Promotional } \\
\text { Tools } \\
\end{array}$} & 4. Formulating statutes and regulations \\
\hline & 5. Providing floor-to-area ratio incentives \\
\hline & 6. Making photovoltaic systems mandatory \\
\hline \multirow{4}{*}{$\begin{array}{l}\text { Push the } \\
\text { subject }\end{array}$} & $\begin{array}{l}\text { 7. Installing photovoltaic systems on public } \\
\text { rooftops }\end{array}$ \\
\hline & 8. Building photovoltaic demonstration zones \\
\hline & $\begin{array}{l}\text { 9. Transforming illegal structures into solar } \\
\text { power providers }\end{array}$ \\
\hline & $\begin{array}{l}\text { 10. Building photovoltaic systems in the fishing } \\
\text { and agricultural sectors }\end{array}$ \\
\hline
\end{tabular}




\section{Creating an Operating Network}

The interdepartmental photovoltaic project task force was established with Kaohsiung deputy mayor as convener, deputy director general of the Secretariat as deputy convener, and the Public Works Bureau as chief managerial office. The task force is in charge of supervising the promotion of the photovoltaic project within the five categories of general constructions, public buildings, schools, factories, and fishing and agricultural facilities. The major and assisting offices in charge of the categories (as shown in Figure 1) work together to fulfill the city's innovative vision.

A dedicated service hotline was set up so as to increase the efficiency and efficacy of installation requests. The service hotline not only takes inquiries and applications, but it is also in charge of collecting statistics and data.

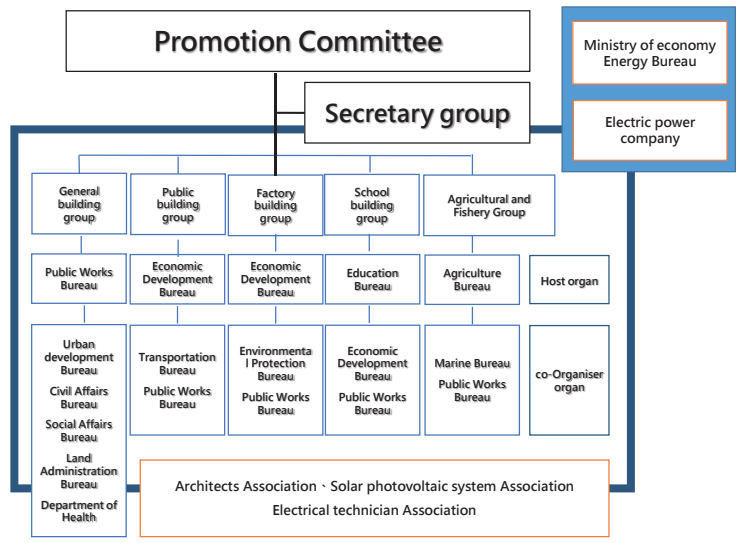

Fig. 1 Plans to promote the organization chart

\section{Utilizing Policy as Promotional Tools}

The Kaohsiung City Government has since 2012 formulated four architectural laws governing the installment of photovoltaic systems. The laws were created so as to promote the generation and utilization of the renewable solar energy.

Through the formulation, execution, as well as review and revision of these statutes and regulations, Kaohsiung's solar photovoltaic systems, intelligent energy management operations, and green building standards have been significantly improved. As the scale of income from promoting green buildings grows, the city is able to continue expanding solar power installments and energy-saving buildings.

Making photovoltaic systems mandatory. The Kaohsiung City Government was able to make photovoltaic installments mandatory in urban areas, open spaces, and the Kaohsiung LOHAS Housing Project by providing construction businesses with incentives during the initial reviewing stages in urban design projects and the licensing review of construction permits.

\section{Designating Exemplary Demonstration Sites}

As action always speaks louder than words, the Kaohsiung City Government took the lead to install solar photovoltaic systems on the roofs of government buildings and public schools using a rental program. In having vendors set up the solar panels, the government is estimated to have saved around NTD 500-700 million in installation and maintenance fees. In addition to giving the city solar energy, the model also creates economic value for the local solar power industry, and at the same time serves as an example of the project's benefits, attracting public attention and recognition. In doing what's best for the environment, Kaohsiung increases its use of renewable energy, helps the solar photovoltaic related industries grow, and ultimately strengthens the city's economic structure and overall competitiveness.

The Kaohsiung City Government has chosen the area surrounding the Pier-2 harbor, the Jhongdou redevelopment zone, and the area of the 2014 Kaohsiung gas explosions as the city's photovoltaic demonstration zones. The goal is to gradually have the installation of photovoltaic systems expand around the zones and ultimately link up to form a photovoltaic power city.

Kaohsiung City prides itself in its counselling rather than punishing attitude when it comes to illegal structures. It encourages owners of illegal structures to convert their illegal rooftop dwellings into photoelectric facilities (Figure 5). It also provides loans and subsidies as incentives to increase interest as well as lower installation thresholds. The new structures, on the one hand, help solve the two most common problems seen in illegal rooftop dwellings, i.e. leaking and overheating, and on the other hand, can be legally built with an additional sunroom compartment. While the city is significantly beautified, the power generated can be sold to the Taipower Company for additional income. As a result, the original hot and stuffy city has the opportunity to be transformed into a pleasant and a steady provider of renewable energy.

\section{Results}

Due to the nature of its development, Kaohsiung City's heavy-industry based economy has come with the price of serious air and environmental pollution. According to statistics, Kaohsiung's annual carbon emissions of 97 million tons make up 25 percent of the nation's total. What's more, each citizen's personal carbon emission is 2.67 times the nation's average.

Over the years, Kaohsiung City has gone through extensive measures to become its own city. In total, Installment capacity increase of $300,000 \mathrm{~kW}$ (or $300 \mathrm{MW}$ ), generated 380 million $\mathrm{kWh}$ of power annually, It can provide the monthly electricity consumption of 104,510 households. Carbon sequestration of about 113 Kaohsiung metropolitan Parks, and created a PV industry with a net worth of NTD 28 billion.

\section{A. General constructions}

Illegal rooftop dwellings are a prevailing and ever-growing problem among Taiwan's residential buildings. Governmental efforts to dismantle the structures are often met with fierce opposition, and the cost to take them down is also an extremely costly burden to the government's finances. Moreover, the illegal structures are a threat to public safety as well as an eyesore to the city's international image.

Converting illegal rooftop dwellings into photoelectric facilities helps solve the leaking and overheating problems often seen in such structures. The facilities also help extend the building's lifespan as well as elevate the residents' overall quality of living (Figure 6). Moreover, statistics show that the temperatures in the top floor drop by $3^{\circ} \mathrm{C}$, and on average, help residents save up to 30 percent power usage. 


\section{B. Factories and traffic facilities}

The Kaohsiung Rapid Transit Corporation worked in collaboration with the country's largest photovoltaic energy service company ( PV-ESCO) to set up several solar photovoltaic devices on its rooftops. The systems were installed with customized fixtures for the buildings' wave-shaped roofing so as to avoid damaging and causing the roofs to leak, which would have consequently lead to massive repairing expenditures. The PV systems were also built with remote monitoring systems for efficient management. In addition to the transit system, Kaohsiung is also home to the country's first Building Integrated Photovoltaic factory.

\section{Public buildings}

To set a good example, the Kaohsiung City Government took the lead to install photovoltaic panels on the roofs of public buildings and also put public building rooftops up for lease to energy service companies. As a result, electricity use was lowered and carbon emission reduced. While helping the local photovoltaic industry grow, the plan helped the government make an extra income.

\section{Agricultural and fishery facilities}

In addition to successfully placing photovoltaic power panels onto the vacant rooftops of public buildings, due to the joint efforts put in by Kaohsiung's multiple offices and departments, the project has also been successful in making powerhouses out of spaces that include commercial structures, agricultural facilities, and residential buildings

\section{E. School buildings}

The plan to lease the rooftops of public office and school buildings for the employment of photovoltaic systems has also been largely successful. By the end of 2018, solar panels could be found on the rooftops of 199 public schools estimated to have a combined capacity of $38.5 \mathrm{MW}$. The buildings are also fully equipped with water-saving appliances and rain storing facilities, and the campus' terrains have been laid with either natural soil or non-woven fabric to ensure the healthy infiltration of water into the soil.

\section{Photoelectric isolation heat effect}

The study is aimed at roof shading. Optoelectronic version, The three types of iron houses are compared. It can be seen from the comprehensive comparison table that, on the whole, The cooling effect is more or less the same.( as shown in Fig. 2) Photoelectric rooftop $>$ iron sheet house $>$ no shading facilities.

The maximum temperature difference between indoor and outdoor facilities without shade facilities can reach 10.8 degrees. Although the temperature difference of the iron hut is the smallest, the temperature of the indoor house is 32.6 degrees 37.4 degrees centigrade. (as shown in Fig. 3 )

A case of solar photovoltaic roofs has been installed. The difference in temperature between indoor and outdoor takes place at least 1.6 degrees in midnight. The maximum temperature difference is about $6.5 \mathrm{C}$ at noon. And the difference between the indoor temperature of the top floor and the body comfort temperature is $22 \sim 26$ degrees. The best set of cases for three modules.

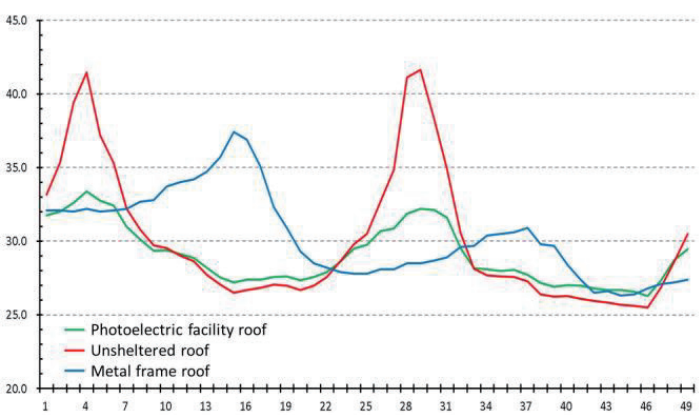

Fig. 2 Comprehensive comparison of roof layer

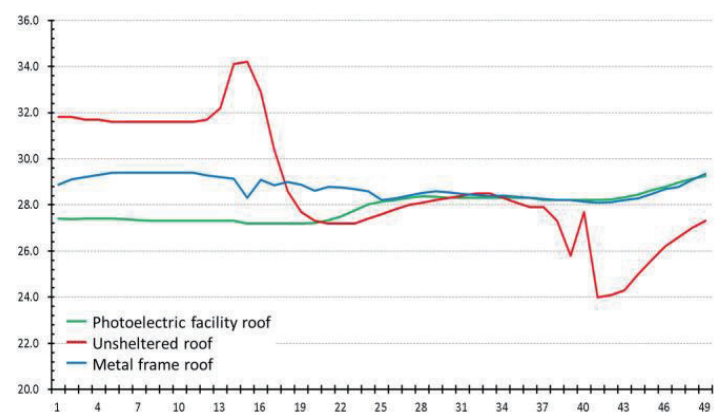

Fig. 3 Comprehensive comparison of floors below the roof

When comparing the three roof modules, Several special states can be compared ( Table II) :

1. Indoor temperature differences as a comparison. The biggest difference was non shading. But it is far beyond comfort zone for photoelectric roof. The last is the iron roof.

2. The best cooling efficiency. The cooling efficiency of photoelectric roofs is better. And the thermal comfort range is relatively close.

3. The future use of space and the measurement of economic benefits. The photoelectric roof can still be used in addition to the lower space. It also generates electricity to provide homeowners back for sale. Manufacturing economic effect. Superior to iron roofs and shaded roofs.

TABLE II

COMPREHENSIVE COMPARATIVE ANALYSIS TABLE

\begin{tabular}{|c|c|c|c|c|c|}
\hline Module & Time & Morning & Noon & $\begin{array}{c}\text { Afternoo } \\
\mathrm{n}\end{array}$ & $\begin{array}{c}\text { Mid-nigh } \\
\text { t }\end{array}$ \\
\hline \multirow{3}{*}{$\begin{array}{c}\text { no } \\
\text { shad } \\
\text { e }\end{array}$} & Roof & $33.2^{\circ} \mathrm{C}$ & $40.6^{\circ} \mathrm{C}$ & $27.6^{\circ} \mathrm{C}$ & $28.3^{\circ} \mathrm{C}$ \\
\hline & $\begin{array}{l}\text { highes } \\
\text { t floor }\end{array}$ & $29.6^{\circ} \mathrm{C}$ & $29.8^{\circ} \mathrm{C}$ & $28.6^{\circ} \mathrm{C}$ & $27.2^{\circ} \mathrm{C}$ \\
\hline & $\triangle \mathrm{T}$ & $3.6^{\circ} \mathrm{C}$ & $10.8^{\circ} \mathrm{C}$ & $1^{\circ} \mathrm{C}$ & $1.1^{\circ} \mathrm{C}$ \\
\hline \multirow{3}{*}{$\begin{array}{l}\mathrm{PV} \\
\text { roof }\end{array}$} & Roof & $30.1^{\circ} \mathrm{C}$ & $35.1^{\circ} \mathrm{C}$ & $30.6^{\circ} \mathrm{C}$ & $27.2^{\circ} \mathrm{C}$ \\
\hline & $\begin{array}{l}\text { highes } \\
\text { t floor }\end{array}$ & $27.5^{\circ} \mathrm{C}$ & $28.8^{\circ} \mathrm{C}$ & $28.1^{\circ} \mathrm{C}$ & $26.8^{\circ} \mathrm{C}$ \\
\hline & $\triangle \mathrm{T}$ & $2.6^{\circ} \mathrm{C}$ & $6.5^{\circ} \mathrm{C}$ & $2.5^{\circ} \mathrm{C}$ & $1.6^{\circ} \mathrm{C}$ \\
\hline \multirow{3}{*}{$\begin{array}{l}\text { Iron } \\
\text { roof }\end{array}$} & Roof & $33.2^{\circ} \mathrm{C}$ & $37.4^{\circ} \mathrm{C}$ & $29.6^{\circ} \mathrm{C}$ & $27.3^{\circ} \mathrm{C}$ \\
\hline & $\begin{array}{l}\text { highes } \\
\mathrm{t} \text { floor }\end{array}$ & $31.6^{\circ} \mathrm{C}$ & $32.6^{\circ} \mathrm{C}$ & $28.6^{\circ} \mathrm{C}$ & $27.2^{\circ} \mathrm{C}$ \\
\hline & $\triangle \mathrm{T}$ & $1.6^{\circ} \mathrm{C}$ & $4.8^{\circ} \mathrm{C}$ & $1^{\circ} \mathrm{C}$ & $1.1^{\circ} \mathrm{C}$ \\
\hline
\end{tabular}


Assess three roof types in the same area. At the same time, a variety of comparative factors are listed below. Analysis of economic benefits of roof form. ( Table III)

1. Shade-free module, although it does not cost any construction costs, but also lost the use of Kaohsiung's congenital conditions, the use of sunlight to generate electricity to produce economic benefits, and the roof and roof are high temperature indoor air conditioning system needs a long time.

2. The cost of photoelectric roof module is about 500,000 yuan, but it is estimated that 80,000 yuan can be recovered every year. The cost can be recovered after 10 years, which can reduce the heating of buildings and the use time of air conditioning.

3. Iron sheet violation modeling group, the early cost is less, but cannot produce any economic benefits, for the building insulation efficiency is similar to the photoelectric system roof.

TABLE III

COMPREHENSIVE ECONOMIC BENEFIT ANALYSIS

\begin{tabular}{cccccc}
\hline Project & cost & $\begin{array}{c}\text { Maintenance } \\
\text { cost }\end{array}$ & $\begin{array}{c}\text { Annual } \\
\text { income }\end{array}$ & $\Delta \mathrm{T}$ & $\begin{array}{c}\text { Air } \\
\text { Conditioning } \\
\text { time }\end{array}$ \\
\hline $\begin{array}{c}\text { no } \\
\text { shade }\end{array}$ & 0 & 7,500 & 0 & $10.8^{\circ} \mathrm{C}$ & $6 \sim 12 \mathrm{hr}$ \\
\hline $\begin{array}{c}\text { PV } \\
\text { roof }\end{array}$ & 500,000 & 0 & 81,650 & $6.3^{\circ} \mathrm{C}$ & $4 \mathrm{hr}$ \\
\hline $\begin{array}{c}\text { Iron } \\
\text { roof }\end{array}$ & 135,000 & 0 & 0 & $5.8^{\circ} \mathrm{C}$ & $10 \mathrm{hr}$ \\
\hline
\end{tabular}

\section{Stage conclusion}

300MW can generate 357 million 700 thousand degrees of total electricity generation per year. The average monthly power generation capacity is about 29 million 800 thousand degrees. Annual electricity generation, It can provide the monthly electricity consumption of 96 thousand and 964 households.

300MW can create 357 million 700 thousand degrees per year. It can reduce 189 thousand and 95 tons of carbon emissions. The amount of carbon dioxide absorbed by 6 million 840 thousand trees. The photoelectric project has been developing until now.

According to the statistics of the industry association, Related solar photovoltaics drive the economic output of the upstream and downstream industries. At least 28 billion yuan. Create more than 1000 jobs.

With the talk of an international carbon tax of NTD 1,940 (EUR 50) per ton of emission likely to become a reality, Kaohsiung City's estimated 30 MW annual photovoltaic output may help lower carbon emissions by 24,276 tons per year. This would amount to saving NTD 47.1 million annually, and a cumulated NTD 924 million in 20 years.

The cost saved from having to dismantle illegal rooftop structures, including paying personnel fees, dispatching vehicles, and processing construction waste, is estimated at NTD 135 million per year, which adds up to NTD 27 billion in 20 years. As the metal roofs of illegal rooftop structures are converted into solar panels, sunshine is absorbed and transformed into electricity, resulting in a drop in the city's scorching temperatures.

\section{References}

[1] Iris A. Junglas, Richard T. Watson, "Location-based services" Communications of the ACM, Volume 51 Issue 3, March 2008.

[2] Seong Yun Cho. "Localization of the Arbitrary Deployed APs for Indoor Wireless Location-Based Applications". IEEE Transactions on Consumer Electronics, Vol. 56, No. 2, May 2010, pp. 532 - 539

[3] N. Montavont, T. Noel, Handover management for mobile nodes in IPv6 networks, Communications Magazine, IEEE. 40, 2002, pp.38-43.

[4] Y.-C. Chen, J.-H. Hsia, Yi-Ju Liao, Advanced seamless vertical handoff architecture for WiMAX and Wi-Fi heterogeneous networks with QoS guarantees, Computer Communications. 32, 2009, pp.281-293.

[5] Q. Song, A. Jamalipour, A quality of service negotiation-based vertical handoff decision scheme in heterogeneous wireless systems, European Journal of Operational Research. 191, 2008, pp.1059-1074.

[6] V. Marques, X. Costa, R. Aguiar, M. Liebsch, A. Duarte, Evaluation of a mobile IPv6-basedarchitecture supporting user mobility QoS and AAAC in heterogeneous networks, Selected Areas in Communications, IEEE Journal 23, 2005, pp.2138-2151.

[7] A. Belhoul, Y.A. Sekercioglu, N. Mani, Mobility-Aware RSVP: A framework for improving the performance of multimedia services over wireless IP-based mobile networks, Computer Communications. 32, 2009, pp.569-582.

[8] C.-Y. Chen, J.-P. Yang, G.-J. Tseng, Y.-H. Wu, R.-C. Hwang, "An Indoor Positioning Technique Based on Fuzzy Logic", 2010 The International MultiConference on Engineers and Computer Scientists, pp.854-857, Hong Kong, 2010

[9] Michael P. Gallaher, Albert N. Link, Alan O'Connor, (2012), Public Investments in Energy Technology, Edward Elgar Publishing.

[10] Sawin, J. L. (2001). The role of government in the development and diffusion of renewable energy technologies: Wind power in the United States, California, Denmark and Germany, 1970--2000.

[11] Sawin, J. L. (2004). Mainstreaming renewable energy in the 21st century (Vol. 169). Worldwatch Institute.

[12] Thomas Friedman, Hot, Flat and Crowded (Picador: New York, 2008)

[13] Ayoub, Nasser, and Naka Yuji. "Governmental intervention approaches to promote renewable energies-Special emphasis on Japanese feed-in tariff.", Energy Policy 43 (2012): 191-201.

[14]Butler, Lucy, and Karsten Neuhoff. "Comparison of feed-in tariff, quota and auction mechanisms to support wind power development." Renewable Energy33.8 (2008): 1854-1867

[15] Couture, Toby, and Yves Gagnon. "An analysis of feed-in tariff remuneration models: Implications for renewable energy investment." Energy policy 38.2 (2010): 955-965.

[16] Campbell, M., Aschenbrenner, P., Blunden, J., Smeloff, E., \& Wright, S. (2008). The drivers of the levelized cost of electricity for utility-scale photovoltaics. White Paper: SunPower Corporation.

[17] Flood, D. J. (2001). Space photovoltaics-history, progress and promise.Modern Physics Letters B, 15(17n19), 561-570.

[18] Fthenakis, V. M., \& Moskowitz, P. D. (2000). Photovoltaics: environmental, health and safety issues and perspectives. Progress in Photovoltaics: research and applications, 8(1), 27-38.

[19] Hammond, A. L. (1977). Photovoltaics-The semiconductor revolution comes to solar. Science, 197, 445-447, p. 445.

[20] Hasnain, S. M., Elani, U. A., Al-Awaji, S. H., Aba-Oud, H. A., \& Smiai, M. S. (1995). Prospects and proposals for solar energy education programmers. Applied Energy, 52(2), 307-314. 